\title{
Towards a national forest policy
}

A definite forest policy ... should be publicly declared and financially sustained through a series of years so as to give uniformity and continuity to its operation.

It is the function of the Federal Government to take the leadership in the formulating and the sustaining of such a policy. The forests render service not to local industries alone, but to industries beyond the provincial boundaries. The Dominion should have an interest even if the forest industries were strictly provincial, for the whole cannot be prosperous if any of its parts lack industrial prosperity, and the forests, as you know, are the second largest contributors to national prosperity. A large portion of our forest products are sold in foreign markets. It is the function of the Dominion government to facilitate and maintain the proper balance in international trade and the consequent parity of exchange. In the past few years, there has been no more important factor in this respect than our forest products sold outside our borders. The Dominion takes leadership in the aid to agriculture, especially along the lines that increase the productiveness of the soil. It is perfectly legitimate and logical that the Dominion take the same interest in the welfare of the forests as in the welfare of the farms, since the forests stand next to the farms as wealth producers and creators of prosperity in this country. There need be no invasion of provincial rights, but there may, however, be need of the sinking of some misunderstandings, shall I say jealousies, in the common good of the Dominion as a whole. I am simply making an appeal for a definite forest policy in this country. Taking the Dominion as a whole, forestry is much in the same condition as that which Mark Twain once described with reference to the weather: "Everybody talks about it and nobody does anything about it". I am simply making an appeal for leadership in a definite forest policy applicable in its main outlines to all parts of the Dominion; a forest policy that shall be based upon two things: adequate protection from fire and the setting aside of definite areas to be dedicated to the production of a continuous supply of raw materials for our wood-using industries. The Dominion is very wide and it presents many problems in forestry as well as in other matters. Many of the problems must be worked out locally. The problems of the East differ from those of the West and the problems of the prairie provinces differ from those of either. Take Eastern Canada, with which I am most familiar, for illustration. Our most critical problem is fire protection. There is great danger that the forest supplies of large industries may be wiped out. Young growth on which we must depend for future supplies is being destroyed at the rate of a half million acres a year in Eastern Canada. I realize that in the present state of our finances, Dominion and Provincial, it is unpopular to talk about spending more money, but we certainly must spend more money and perfect our protection organizations if we are to save our forests. We are now spending in the neighbourhood of a million and a half dollars on forest protection in the East. This sum should be doubled. The money must be found in some way. It is entirely logical that the Dominion government should take the leadership in this. The problem affects the eastern half of the country and 70 per cent of its population. Is it, therefore, not a national problem? The Dominion spends about six million dollars a year in encouraging agriculture, a private enterprise. I say again that the forests stand next to the farms as wealth producers. I ask again, is not their protection and intelligent use a national problem?

There is nothing hard to understand about those two principles of adequate protection and continuous production. There is nothing mysterious, nothing abstruse about forestry. Like other things worth while, a national forest policy will cost money, energy and intelligent planning. In fact, a definite forest policy is a national investment. It rests upon the sound economic principle of whirring wheels, sustained labour, prosperous and permanent population in districts devoid for the most part of agricultural possibilities, designed in the beginning by the Creator for the growing of forests and granted to an intelligent and virile people. These gifts are yours; what will you do with them?

The above is extracted from an address by C. D. Howe, President of the Canadian Society of Forest Engineers, before the Royal Canadian Institute at the Physics Building, University of Toronto, Saturday evening, March 28, 1925.

The address was printed in the first issue of The Forestry Chronicle.

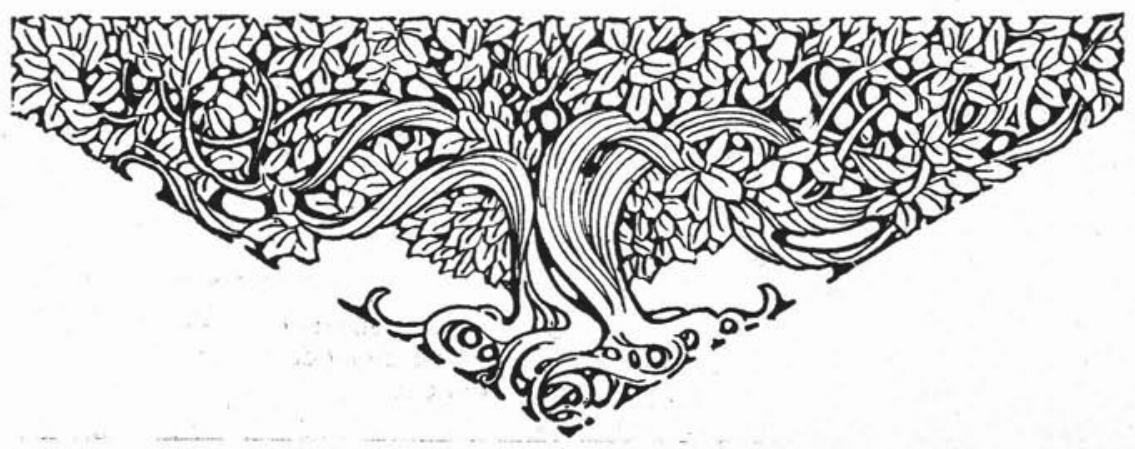

